International Journal of Applied Linguistics \& English Literature

ISSN 2200-3592 (Print), ISSN 2200-3452 (Online)

Vol. 1 No. 6; November 2012

\title{
Literature of a Crisis: The Great War in Anglo-American Modernism
}

\author{
Shadi Neimneh \\ English Department/Faculty of Arts, Hashemite University \\ Zarqa-Jordan, 13115 \\ Tel: (962)779148865 \\ E-mails: shadistar2@yahoo.com; shadin@hu.edu.jo; snaamneh@excite.com
}

Received: 12-07- 2012

Accepted: 08-08- 2012

Published: 01-11- 2012

doi:10.7575/ijalel.v.1n.6p.122

URL: http://dx.doi.org/10.7575/ijalel.v.1n.6p.122

My subject is War, and the pity of War. -Wilfred Owen, 1918

\begin{abstract}
This paper looks at the representation of war in fiction as a catastrophic social event. In studying or teaching the Great War as represented in modernist literature, we have to acknowledge that fiction, and despite its overlap with history or historical value, is not mere history. War literature retains a powerful sociological orientation. The novels discussed in this paper push real war action to the background and highlight, instead, the impact of war on the subjective lives of individuals and their social interaction. Modernism is not primarily concerned with accurately reproducing the war, but rather with impressionistic details, i.e. the impact of war on introverted lives. Therefore, the real value of such novels is not documentary or historical but social and psychological.
\end{abstract}

Keywords: Modernism; Anglo-American Fiction; the Great War; Representation; Social Reality

\section{Introduction}

The Great War was arguably the biggest public event in the first half of the twentieth century. It figured prominently in the last century's canonical literature and became the literary war par excellence. As Steven Matthews (2004) argues, it "instigated radical changes in the form and content of literary texts in English" (p. 62). However, the representation of this war in the literature of its era, and especially in the war's aftermath, was far from the merely objective or historical. Rather, the effects of this war on society and its individuals were an increasingly typical focus. The interrelationship between the individual and the larger social order was manifested in the interplay between the domestic, private lives of individuals and the public event of this war. While the novels written about the Great War in the 1920s within the Anglo-American literary canon do sometimes record its action, the larger social stance is usually more important than the historical or autobiographical dimensions. The war gets contextualized within a social atmosphere of loss, sickness, and sterility. Hence, it often becomes "the absent presence" that haunts the lives of its survivors and forms their outlook. It is used to symbolize aspects of the larger social order and cultural climate. It is the somberness and death that haunt T. S. Eliot's The Wasteland (1922) and the alienation and communal cultural exhaustion in his "The Hollow Men" (1925). It is the essence of the modernist sensibility in terms of a sense of loss of traditional values, pessimism, metaphysical suspicion, and fragmentation. It destroyed typical notions of heroism and masculinity through mass slaughter and maiming of men. It created an apocalyptic cultural crisis and disrupted human relations. Malcolm Bradbury (2001) notes that "Directly or indirectly, the wound of war was everywhere in the post-war novel, explaining the note of sharp generational change, historical weariness, waste-land vision and rootless psychological tension so plain in much of the best fiction" (p. 145). Hence, if the war itself is pushed to the background and if the war action is secondary, more important is how characters mentally live the war or just live their lives during and after it. Within Anglo-American modernism, the subjective view of the horrible reality of the war, characters' reaction to the war, and the war's milieu are given the priority over any documentary value about the war the novels might have. Although this is not meant to denigrate the historical value of such novels, more important is the modernist view of reality the novels negotiate.

Critics who studied the Great War in literature have covered things like its apocalyptic, dehumanizing or ironic nature by way of assessing its impact and capturing the sensibility it effected. John Muller (1991) argues that one

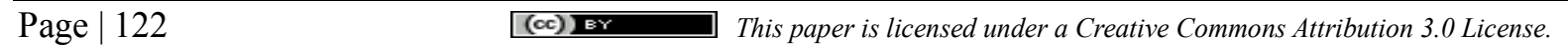


of the reasons why the Great War is probably unique is that "it raised the spectre that through some combination of aerial bombardment and gas or bacteriological poisoning the next large war could lead to world annihilation - the destruction of winner and loser alike" (p. 17). Alfred Bonadeo (1989) explains that "[t]he waste changed man into an inferior being, and the price he paid for valor and survival was degradation" as war "left many men physically alive but spiritually dead" (p. 2). Paul Fussell (1975) dwells on the ironies associated with this war, i.e. how the consequences were always incongruous with the expectations or how the cost was incongruous with an achievement. "Every war is ironic," writes Fussell, "because every war is worse than expected" (p. 7). "But the Great War," he continues, "was more ironic than any before or since. It was a hideous embarrassment to the prevailing Meliorist myth which had dominated the public consciousness for a century. It reversed the idea of progress" (p. 8). The war, Fussell argues, changed out conception of historical continuity because it disrupted a "seamless, purposeful 'history' involving a coherent stream of time..." (p. 21). However, and despite such insightful comments, these critics have not detailed the social context of the war and the interplay between the private experience of individuals and the public event of the war as represented in modernist war literature.

Samuel Hynes (1991) offers a more useful model in this regard. Discussing Virginia Woolf's To the Lighthouse, he asserts that she wrote about "time, change, the irrevocability of loss, the ecstatic sharpness of the felt moment. But her novel is located in history, and like The Waste Land it has a historical vision" (p. 345). War for writers like Woolf and Eliot is part of their imagination and understanding of history, part of the lived reality of chaos, destruction, and fragmentation because they, Hynes writes, write about "no battle scenes, no heroes, and no victories; they pick up from the war only the dominating negative themes - the death of civilization and the loss of Eden, and the negative characters - the deranged victims, and the tyrannous Old Men. And they construct out of this heap of broken images the forms of the history of their own time" (p. 348). This means that these writers are more concerned with the cultural and social aftermath of the war than with the war itself. The war for them is a mere historical incidence with paramount ramifications. Hynes gives a useful division highly relevant here: "There are two basic narrative forms into which war narratives divide: call them the Autobiographical and the Historical, or the Personal and the General, or the Small Picture and the Large" (p. 425). The "Historical" and "Large" form Hynes refers to concerns the larger context of the war and not simply the private experiences of a soldier covering war action mainly and written in the form of a memoir. In this larger approach, what is before the war or after it is as important as what is during it. This approach makes war the agent of social and historical transformations.

While Hynes covers mainly the British literary scene, William Matsen (1993) notes a similar shift in the treatment of the Great War in American fiction in the (late) 1920s and (early) 1930s and a shift in literary realism from the early novels of "witness and testimony" (p. 10) based on events witnessed and war actualities to more creative and fictional novels still revolving around the war, a shift seen by the author as an important development in American literature of the war: "Thus," writes Matsen, "there is a development within the sub-genre of the war novel form narratives that are strongly mimetic and near journalistic to more finely crafted works of fiction" (pp. 10-11). This means that writers would give more attention to plot, character development, structure, theme, imagination ...etc. Indirectly, more emphasis on the creative, imaginative representation of war places it within a broader social context. Matsen implies that documentary reporting in memoirs and autobiographies about the war was diminished in the sake of craft and human relations in a more fictionalized form. Verisimilitude gave way to more focus on the impact of war on individuals, on war as part of the human experience and not as the sole one, which is what I highlight by looking at the social context of the war in some Anglo-American novels published during the early twentieth century.

\section{The Great War and Anglo-American Modernism: A Reading of Selected Works}

2.1British Modernism and the Great War

In The Death of a Hero (1929), Richard Aldington juxtaposes the anarchy of the war against the anarchy of personal relations and life early in the twentieth century England. Aldington satirizes the frivolous society of England before the war and sees in the war a logical outcome to such social decay. In fact, the war itself is given one section of the novel, and the first two are given to the social milieu of the war, what is before it, and what is after it. It is also significant that we learn about the "hero's" death in the beginning of the novel as we see how his family and wife and mistress react to his death in the distant French trenches. The bohemianism and complacency of pre-war middle-class life constituted the climate that would victimize him and damage his life in the same way the war did. Aldington, as Bernard Bergonzi (1980) argues and as the ironic title of his novel hints at, undertakes "a savage debunking of the whole concept of heroism" (p. 182). His unheroic hero was robbed of masculinity by both social hypocrisy and war action. His novel is set against "an atmosphere of stifling Victorian respectability" (p. 
183). The young generation was unprepared for adult relations and sexual freedom by repressed, hypocritical, and morally loose parents. And the young generation was equally fickle.

The young women between whom George Winterbourne is torn forget him and take other lovers once he is drafted in France. When he is back for training, they are bored with his constant talk about the war. He has been cut off from life and war became his only reality, the only thing he knows. They go out with other men, and he leaves back to the front feeling inadequate, ill-suited. He is then censured by his colonel for the faults of cowardly, untrained men. He feels he cannot go on with life. Once George Winterbourne dies, his name is mentioned briefly, and ironically, in a list under the title "Killed in Action" (p. 3). His secular mother shed tears which "were not very natural" (p. 6) and had "very little belief in the value of prayer in practical affairs" (p. 7). The hypocrisy of his mother's feelings is not different from those of Elizabeth, his wife, who is ready to receive his state and other "military effects" (p. 13). He and Elizabeth had believed that "freedom, complete freedom, was the only solution" for marriage problems (p. 17). As soon as he leaves for military training, Elizabeth and Fanny are already "absorbed in other 'affairs"” (p. 20). George's home and front lives unmanned him, and the narrator himself feels implicated in the communal guilt: "The death of a hero! What mockery, what bloody cant. What sickening putrid cant. George's death is a symbol to me of the whole sickening bloody waste of it, the damnable stupid waste and torture of it. You have's seen how George's own people - the makers of his body, the women who held his body to theirs - were affected by his death. The Army did its bit, but how could the Army individually mourn a million 'heroes'? How could the little bit of Army which knew George mourn him?" (p. 28). While George was an insignificant victim of the war machine, he was also betrayed by people at home and even long before the war began.

The Victorian England of 1890 that produced George is "morally buried in great foggy wrappings of hypocrisy and prosperity and cheapness" (p. 33). His father married because his mother was "a dominating old bitch who destroyed his initiative and courage" (p. 34). George's mother, on the other hand, had had many lovers and married what she took to be a rich husband, a man who "continued to play at being 'rich' on his honeymoon" (p. 48). Such a private family background of impotence and selfishness makes him unfit for the more chaotic and public war atmosphere. The narrative, then, oscillates between the private plight of individuals and the public war action. At the front, "[t]he very apparatus of killing revolted him, took on a sort of sinister deadness" (p. 250). He sees some new drafts one morning and feels a strange feeling of intimacy with these men as he is repulsed by the fickle women at home: "For the first time since the declaration of War, Winterbourne felt almost happy. These men were men. There was something intensely masculine about them, something very pure and immensely friendly and stimulating" (p. 263). When women are a negative influence and a distraction and men at home are lacking in vitality, male intimacy with other soldiers becomes an avenue of hope and escape. George thinks to himself: "I swear you're better than the women and half-men, and by God, I swear I'II die with you rather than live in a world without you" (p. 264). He admires the "manhood and comradeship" of these men whether German or allied (p. 269). The typical anti-war message is clear when the enemies of these men are not each other but "the fools who had sent them to kill each other instead of help each other" (p. 269). The false ideals and corrupt leadership associated with the war are attacked and common humanity is celebrated (p. 269).

Aldington juxtaposes against the sterility of George's home life the bitter reality of war action. As in traditional war novels, brutal realism is used to convey anti-war sentiments: "It was like living in the graveyard of the world - dead trees, dead houses, dead mines, dead villages, dead men” (p. 280). In the war section, we hear about and see the cold, rats, diarrhea, German prisoners, skeletons, helmets, rusty rifles, shell-holes, cut trees, debris, and decaying corpses. The section is also colored by other references to the humiliations of trench warfare: lice, excrement, tear-gas, muddy trenches, the roar of guns, rumors about the brutality of Germans, etc. George once tramples unconsciously a dead German corpse (p. 317). Men badly wounded and groaning, mutilated corpses, and chance killing and survival are all depicted, not simply to document trench warfare but rather to highlight the emotional deterioration of the protagonist: "Winterbourne began to feel as if he had made a pact with the Devil, so that other men were always being killed in his stead" (p. 354). Precisely put, Winterbourne "endured a triple strain - that of his personal life, that of exasperation with Army routine, and that of battle" (p. 301). The personal is thus constantly juxtaposed against the public event of the war.

At the front, Winterbourne suffers from "the torment of frost and cold; now came the torments of mud, of gas, of incessant artillery, of fatigue, and lack of sleep" (p. 310). At night, he struggles against big rats jumping on his body (p. 343). But when he is on leave, things are no better; he is still alienated from others and even unable to paint as he used to do or resume his normal life. War memories continue to haunt him at home. His love life on these leaves is a failure. The women he knows have affairs and do not understand him. He returns to the front as an 
officer, and he is in charge of a company. He is sad at their young age and inexperience: "He felt it was monstrous to send these school-looking boys into the line without a proper stiffening of more experienced men" (p. 379). Shells fall on a cemetery and dig up graves and remnants (p. 381), and he loses friends in action. He also loses men in his company and has trouble with intolerant superiors. The interplay between the private and the public logically leads to the end. "All the decay and death of battle fields entered his blood and seemed to poison him" (p. 386). At the end of the war and in November of 1918, the German are losing and retreating. Just before a big counterattack, he tries to write letters to Elizabeth and Fanny but is unable to think (p. 390). He is despairing and gloomy. He stands up during a German machine-gun attack in which many of his men are killed and is himself killed: "Something seemed to break in Winterbourne's head. He felt he was going mad, and sprang to his feet. The line of bullets smashed across his chest like a savage steel whip. The universe exploded darkly into oblivion" (p. 392). He dies repulsed by the hypocrisy of his home life, fake relations, bohemianism, and lies. The horrors of the front combined with his personal problems led to his suicide, and the narrator tells his story because he feels he is also to blame for George's suicide. After all, the narrator is part of the society that produced George; the narrative becomes an elegy for the soul of the dead George from a survivor who "needs the atonement of his written account" (Willis, Jr., 1999, p. 479). Briefly put, although this novel records war action and incorporates social realism in the process, it contextualizes George's suffering and death within the larger social corruption of Victorian morals and upbringing to the extent that his final death is a suicide driven by his inability to come to terms with both the horrors of the trench as well as his home life. The war setting in the novel highlights the moral and spiritual bankruptcy in the characters' lives.

Virginia Woolf similarly records the catastrophic impact of war on human life and human relations. In To the Lighthouse (1927), Woolf revisits the war indirectly within a project documenting the changes brought by war and modernity. In between "The Window" and "The Lighthouse" sections, she inserts a short, hurried chapter entitled "Time Passes." This chapter covers a ten-year time span and is dominated by loss, rupture, change, darkness, and decay. The time that passes covers the war years and brings about the shift from the stable Victorian and Edwardian lives to the world of change and loss of the 1920s. The war is rendered as a break in continuity, a disruption of life and a dislocating experience. Hence, the fragmentation of experience characteristic of modernism and the impact of the war are interwoven and rendered aesthetically as an abrupt chapter that fragments the continuity of the narrative.

But war in the novel is never a direct experience. We incidentally hear about the damage it does to human life and nature. Allyson Booth (1996) rightly argues that in Woolf's To the Lighthouse war "is reported by an ambiguous narrator lodged in an empty house; the reporter relies on no witness, details no wound, and elicits no response. War here is the sound of hammers dulled on felt, the vibration of tumblers in a cupboard, the thud of something falling" (p. 3). War is often experienced vicariously as part of the cosmic confusion and disorder that haunt this section. The deserted house of the Ramsay family endures the passage of time and its destructive effects. The house that was once full of life and social gatherings now suffers from natural loss and decay just like the distant battlefields: "The nights now are full of wind and destruction; the trees plunge and bend and their leaves fly helter skelter until the lawn is plastered with them and they lie packed in gutters and choke rain pipes and scatter damp paths" (p. 131). The sudden death of Mrs. Ramsay then signals the death of conventional certainties of an earlier era like family life, optimism, and benevolence. Her ghost haunts the deserted house, and the deserted house becomes an objective correlative for the expression of emotions of loss, lament and change brought by the passage of time and war.The deaths of Mrs. Ramsay, her son, and her daughter are reported in brackets in this section to indicate their suddenness and insignificance in the larger scheme of things like time and war. In the case of Mrs. Ramsay, this is what we encounter: "[Mr. Ramsay stumbling along a passage stretched his arms out one dark morning, but, Mrs. Ramsay having died rather suddenly the night before, he stretched his arms out. They remained empty.]" (p. 131). The empty, silent house gets dusty and mouldy with moth in the clothes left. Mrs. McNab, the cleaning woman, struggles to bring it to order, for women, it seems, struggle to put things in order unlike men who brought all the war destruction. Then we know parenthetically about another death: "[Prue Ramsay died that summer in some illness connected with childbirth, which was indeed a tragedy, people said. They said nobody deserved happiness more.]" (p. 134). Immediately after this we encounter Andrew Ramsay's death in battlefield, again parenthetically: "[A shell exploded. Twenty or thirty young men were blown up in France, among them Andrew Ramsay, whose death, mercifully, was instantaneous.]" (p. 135). The war is distant yet its effects are strongly felt everywhere in this section. Death in war is rendered in an aside just like natural death and death in childbirth. The fact that we have been prepared for this war death through the death and decay ravaging the house and the changes brought by the passage of time juxtaposes the domestic against the political. 
Heat, sun, wind, and weeds all affect the house and the war, symbolized in a sprawling, wild, and hostile nature, echoes in the background. It becomes the collective, disembodied groan of pain experienced by soldiers and civilians alike: "Now and again some glass tinkled in the cupboard as if a giant voice had shrieked so loud in its agony that tumblers stood inside a cupboard vibrated too. Then again silence fell; and then, night after night, and sometimes in plain mid-day when the roses were bright and light turned on the wall its shape clearly there seemed to drop into this silence this indifference, this integrity, the thud of something falling" (p. 135). The desolate house itself is like a desolate battlefield: "There it had stood all these years without a soul in it. The books and things were mouldy, for, what with the war and help being hard to get, the house had not been cleaned as she [Mrs. McNab] could have wished" (p. 136). The war disrupted not only the cleaning ritual of the house but also the summer vacations in it for a long time. Mrs. McNab thinks: "And once they had been coming, but had put off coming, what with the war, and travel being so difficult these days; they had never come all these years; just sent her the money; but never wrote, never came, and expected to find things as they have left them, ah dear!" (p. 137). Mrs. McNab's consciousness dominates this section for a while, for she is the hope of rescuing the house from ruin and imposing some order on the chaos of a violent modernity. She thinks about Mrs. Ramsay and her family. She remembers the sudden deaths of Mrs. Ramsay, her daughter, and her son being killed in the war. She sadly considers the ravages of war and surmises that "many families had lost their dearest" and that "every one had lost some one these years" (p. 137). The war, hence, figures prominently through its impact on human life even when its action is over.

While time destroys, it also restores. The gradual post-war awakening begins with Lily Briscoe and Mr. Carmichael returning to the house after "[m] essages of peace breathed from the sea to the shore" (p. 141). With the help of Mrs. Bast, Mrs. McNab restores the house to order. Once war is over, life in the summer house is back, though ultimately changed. Hence, war here is decay and destruction of the war years as felt by those away from the front lines and as echoed in natural violence and decay. Woolf presents a unique feminist vision of the social context of war. As a woman, her focus is not war action in itself but the war as felt and experienced at home, especially in the loss of Victorian womanhood ideals represented by Mrs. Ramsay as the Angel in the House and death within families. Tammy Clewell (2004) highlights a project of mourning Woolf is engaged with and how this "was stimulated by the cataclysmic traumas of the First World War" (p. 198). "In her sustained effort to confront the legacy of the war," Clewell argues, "Woolf repeatedly sought not to heal wartime wounds, but to keep them open" (p. 198). For Clewell, Woolf refuses to "engage a process of mourning aimed at 'working through' despair and grief" (pp. 198-9). For Clewell, Woolf's project of negative "endless mourning compels us to refuse consolation, sustain grief, and accept responsibility for the difficult task of remembering the catastrophic losses of the twentieth century" (p. 199). Woolf's apparent pessimism is in tune with the modernist sensibility in the aftermath of the war. It is also true that many writers compulsively returned to the war and repeated its trauma in their works. However, Woolf shows in the figure of the artist Lily Briscoe who returns to the house after the war and completes a painting of Mrs. Ramsay and the figure of the cleaning woman Mrs. McNab an enduring feminist principle and a glimmer of hope within a scheme of change and disorder.

D. H. Lawrence in Lady Chatterley's Lover (1928) also contextualizes the war more directly within cultural decline and social changes. The dark vision of the war is given within the context of the destructive forces of industrialism/mechanization, changed attitudes to the arts, the passing of old England, class prejudice, and lost countryside. In the midst of chaos brought about by the war, cultural degeneration, and industrialism, Lawrence seems to offer human love and healthy sexual relations uncontaminated by industrialism and materialism as the hope. Sir Clifford's war wounds have left him impotent and on a wheelchair. His young wife, unsatisfied with the marriage, falls for the gamekeeper Oliver Mellors. Clifford's wounds are symptomatic of modern sterility, cultural hollowness, and weakness of the post-war Britain and his class in particular, the landed aristocrats. When his body is damaged by the war, he becomes more intellectual and money-minded, a writer and an industrialist, with no attachment to the earth he damages in his mining business. The environmental damage and exploitation he does contrast with the vigor and fertility of the sexual relationship between Connie and Mellors and Mellors's care for the land and animals. Clifford's estate stands for the over-intellectualism and abstraction of the post-war generation, for emasculated, hollow men as opposed to the pastoral woodland surrounding the estate where sex is part of natural life. Wragby Hall in the English Midlands is a place where petty writers, playwrights, and intellectuals meet and aimlessly discuss life and art. The post-generation is rendered powerless, bitter, isolated, and sterile. It can achieve nothing beyond financial gain or superficial talk. This novel then restates Lawrence's views on sexuality and modern life, notions elsewhere publicized in his fiction and criticism. Sex is renewal and regeneration, an escape from intellectualism and industrialism. It is neither dirty nor pornographic. 
The novel laments the passing of an era and cottage England and the tragedy of the war, and yet affirms life force over death. It begins: "Ours is essentially a tragic age, so we refuse to take it tragically. The cataclysm has happened, we are among the ruins, we start to build up new habits, to have new little hopes. It is rather hard work: there is now no smooth road into the future: but we go round, or scramble over the obstacles. We've got to live, no matter how many skies have fallen" (p. 37). The war has disrupted human relations and the family institution. In the case of Constance Chatterley, the war "had brought the roof down over her head. And she had realized that one must live and learn" (p. 37). We immediately know that she married a soldier in 1917 on a leave from the battlefield. They have a honeymoon and he goes back to Flanders "to be shipped over to England again six months later, more or less in bits" (p. 37). He is cured but with "the lower half of his body, from the hips down, paralyzed for ever" (p. 37). This disability made him distant, cold, infantile, and psychologically and physically scarred. Clifford had a brother dead in the war in 1916, and he now knows that he "could never have any children" (p. 37). Their father, hence, dies knowing that his children could not provide an heir for the family line and property. Connie and her sister had already had German lovers they met in their school years who died in the war in 1914. So, the present lives of these characters are intertwined with their past and the impact the war left. War in this novel is more felt in its impact on human relations than seen in its action.

Connie is stifled in her life with a war-crippled husband. She feels that she "had lost touch with the substantial and vital world" in Wragby (p. 55). All she can see is "Clifford and his books, which did not exist . . which had nothing in them! Void to void" (p. 55). The intellectuals who visit Wragby are enslaved to commercialism and "the bitch-goddess" of success (p. 56). They all, the post-war generation, believed "in the life of the mind" (p. 68). Their intellectualism takes from their belief in life force. They are spiritually empty, restless, abstract, and superficial. This internal void is juxtaposed against another external one, also caused by the war, for in the woods surrounding Wragby, "there was no game; no pheasants. They had been killed off during the war, and the wood had been left unprotected, till now Clifford had got his gamekeeper again” (p. 79). During an outing with Clifford to the woods, Connie notices the damage done to trees and natural life in the lifeless and "forlorn" cut trees forming a clearing: "This was one of the places that Sir Geoffrey had cut during the war for trench timber. The whole knoll, which rose swiftly on the right of the riding, was denuded and strangely forlorn. On the crown of the knoll where the oaks had stood, now was bareness" (p. 80). She feels the effects of the war everywhere, in the mood of restlessness and unrest around her, in physical and psychological damage: "The bruise was deep, deep, deep . . the bruise of the false inhuman war. It would take many years for the living blood of the generations to dissolve the vast black clot of bruised blood, deep inside their souls and bodies. And it would need a new hope" (p. 89). As always in Lawrence, the body as a vital force is glorified in this moral wasteland: "Something echoed inside Connie: 'Give me the democracy of touch, the resurrection of the body!"' (p. 117). While she feels enslaved and yearns for sexual fulfillment, Clifford is lost in his industrial mining business and his books and becomes something like a machine, something "with a hard, efficient shell of an exterior and a pulpy interior, one of the amazing crabs and lobsters of the modern, industrial, and financial world, invertebrates of the crustacean order, with shells of steel, like machines, and inner bodies of soft pulp, Connie herself was completely stranded" (p. 156). He represents the new order of industrialism and mechanization, and in him we see the novel's critique of modernity: "those evil electric lights and diabolical rattlings of engines" (p. 167). Mellors, on the other hand, is the new morality, the restorative vision and glimpse of hope for Lawrence. He is clean and pure, uncorrupted by guilt, greed, or sin, free from shame that is fear, "old physical fear" (p. 312), industrialism, and capitalism. He believes in being "warm-hearted" and especially in "love" (p. 266). Mellors, like Connie, is made lonely with destroyed marriage after the war, as he comes back from military service in India to find his wife with another fellow (p. 261). Connie tells him that the new industrial generation men became "labor-insects, and all their manhood taken away, and all their real life" (p. 282). Their fulfilling love is an anti-dote to the sterility of the postwar atmosphere. The damage done by the war to men, to the bodies and psyches, as well as the repercussions of this damage on human relations is what is at issue in Lawrence's text and what gives the war a social context as a critique of modernity.

\subsection{American Modernism and the Great War}

Having looked at the representation of the Great War in representative works belonging to the British modernist canon, it is time to examine some selected works from the American modernist tradition and in terms of their social commentary on the Great War and its aftermath. John Dos Passos in Manhattan Transfer (1925) represents the complex, speedy urban experience of life in New York. Plot in the traditional sense is absent behind overlapping narratives of many characters, something to capture the transfer stations of the New York subway system. The view is a pessimistic one of a decadent city. Although not primarily about the war, the novel depicts, in its fragments, the plight of poor returning soldiers, shows the excitement people feel at the beginning of the war, and 
shows the disillusionment with the war's aftermath and the lack of change the war effected. The critique of a disorientating modernity is intertwined with a critique of the war. The novel is more concerned with the impact of the war on modern life and individuals. Dutch Robertson is a returning veteran who is poor and becomes a prisoner for crime. Other returning veterans ask for bonuses for the missed economic boon. Others go to Europe during the war to work for the Red Cross. The representation of the war is in line with the novel's whirlwind style of throwing many things and not exhausting anything. There is much left to the reader to infer and connect. We never leave New York. We just hear about the war or encounter the disillusioned returning veterans who unavailingly seek privilege or jobs. However, the gap between classes continues after the war and jobs remain scarce. Captain James Merivale calls it "a great little war while it lasted" (p. 256). Elmer, a radical believer in revolution, tells his girlfriend Ann that the war continues and is not simply over. The war is thus offstage, constantly alluded to yet never seen in its action. We hear about the war every now and then from characters discussing politics, often in passing. The war haunts them, but the novel does not document war action for a historical end.

By the time the war breaks out, one character, Jimmy, decides to go to Europe to work as a war correspondent, and another, Ellen, wants to serve in the Red Cross as a nurse (p. 214). Referring to the war, one character reveals how it preoccupies people's lives: "This war. I can't think of anything else" (p. 205). Congo, a Frenchman who came to work in New York, says that he won't go to the war and that "A working man has no country" (p. 214). He wants to be an American citizen instead to move upwards and thinks the war is being fought "So that working men all over won't make big revolution. .. . Too busy fighting” (p. 214). Joe O'Keefe, a returning soldier, and Joe Harland discuss the war. "I don't see how this can last long," says Harland (p. 224). O'Keefe, now a Sergeant-major, and Private $1^{\text {st }}$ Class Dutch Robertson, his friend, return ambitious, wanting jobs, marriage, and a good life at home. O'Keefe leads a meeting for an organization of fellow ex-veterans and is mad at the scarcity of jobs and bonuses. He says: "We fought for 'em didn't we, we cleaned up the squareheads, didn't we? . . And now when we get home we get the dirty end of the stick" (p. 267). He rants about lack of jobs and losing their girls who married other men during their absence. He stirs people against the government. Gus McNeil warns O'Keefe against agitation committees and subsequent violence like raids on the Garment Workers' Ball. He tells him: "I tell you, Joe, the people of this country are pretty well fed up with war heroes" (p. 295). And he adds that "A national bonus means taxes to the average business man and nothing else. . . Nobody wants no more taxes" (p. 295). However, all this zigzag talk about the war never reaches a satisfactory sense of closure, and the novel offers just snapshots about the war. Each time the war is mentioned, Dos Passos transfers the discussion immediately to other things. So, the war is seen as part of the fragmented, speeded up experience of modernity. The point is not to render war action but to contextualize war within changing times and human relations. That is, the impact of the war is more important than the war itself as the war is politically over now. Violent deaths through drowning or fire recorded in the novel and a speedy, fragmented life are in tune with the war atmosphere and its effects. The novel recreates the experience of a modernity shattered by the war. The violence and destruction of the war are made sudden and sweeping, which is in line with the novel's swift nature.

Ernest Hemingway similarly shows how the war impacts human life and relationships, but he seems less concerned with the experimental spirit of Dos Passos. In The Sun Also Rises (1926), we clearly see the effects of war on a whole generation. The war is in the background, in the memory of characters, in their conversations, in their outlook, and in their allusions. Jake Barnes and his coterie in Europe stand for post-war disillusionment, cynicism, loss, spiritual void, and ennui. This generation lost its faith in such values as love, religion, womanhood, and manhood. Jake's physical wound he received fighting with the Italians is symbolic of the psychological, physical, and moral damage of the war on an entire generation - the expatriate group. Jake's wound that rendered him impotent is a physical manifestation of what other characters suffer emotionally and socially. He becomes Hemingway's postwar Fisher King in his impotence/emasculation that is symptomatic of the sterility around him. His personal plight that he carries from the war action contrasts with the emotional plight of other survivors who are intact in body yet touched in soul. War made these young expatriates homeless, faithless, restless, hollow, alcoholic, and emotionally paralyzed. It made them without families and without a near past aside from the war. Their sexual and social roles were changed by the war as well. Their possible redemption in an amoral world lies in sports, nature, stoicism/moral strength, skill, and true friendships. With an epigraph and a title from the Book of Ecclesiastes and another epigraph from Gertrude Stein about the lost generation, "You are all a lost generation," the novel comments on an entire generation destroyed by the war, a commentary that provides the social context for the war. However, the futility of sex, alcohol, and violence will not eradicate all human values, as something will inevitably endure. The abiding sun and the passage of time and generations in the second epigraph offer some hope: "One generation passes away, and another generation cometh; but the earth abides forever. . The sun also 
International Journal of Applied Linguistics \& English Literature

ISSN 2200-3592 (Print), ISSN 2200-3452 (Online)

Vol. 1 No. 6; November 2012

ariseth, and the sun goeth down, and hasteth to the place where he arose ..."For Hemingway, consolation lies in transcending a traumatic history.

Hemingway still captures the essence of the postwar modernist sensibility in terms of disillusionment with the war and cultural dislocation/decay. The sickness motif generalizes the decay and destruction of the war and highlights the impotence it effects or the heroism it takes. Jake accidentally meets a prostitute in Paris. They take a cab ride and she tries to touch him. He takes away her hand affirming he is sick. "Everybody's sick. I'm sick, too" she replies (p. 16). Jake, in his alienation, picked her because "of a vague sentimental idea that it would be nice to eat with some one" (p. 16). When she asks about the nature of his sickness, he just says "I got hurt in the war" (p. 17). The ambiguous war injury is meant to allegorize the whole sickness of war and the botched civilization it resulted in. She responds "Oh, that dirty war," and Jake says: "We would probably have gone on and discussed the war and agreed that it was in reality a calamity for civilization, and perhaps would have been better avoided. I was bored enough" (p. 17). Masculinity had to be redefined as the injury done to the male body in a mechanized war made it weak and impotent. Hence, the new woman represented by the English Lady Brett Ashley, Jake's counterpart, is a reaction to the disrupted gender roles. Heroism now is in dignity, precision, honesty, direct confrontation with reality, and passion, all embodied in bullfighting.

The cynical, disillusioned attitude characters have is typical of the postwar lost generation. They are the generation that fought the war in France and then expatriated themselves from America and Britain. Bill Gorton, a war veteran, captures the essence of expatriate life when he tells Jake: "You're an expatriate. You have lost touch with the soil. You get precious. Fake European standards have ruined you. You drink yourself to death. You become obsessed by sex. You spend all your time talking, not working. You are an expatriate, see? You hang around cafés" (p. 115). However, Jake is more pragmatic and morally stronger than other Paris café society expatriates. Cohn sees in him his only friend and begs him for forgiveness after he insults him (p. 194). Others express to him their anxieties and fears, even beat him and apologize; and he accepts. Unlike other expatriates who turn to alcohol, sex, art, and violence as alternatives in the postwar cultural futility, he finds meaning and order in bullfights, bravery, earnestness, self-control, grace, and integrity. The code of values of the bullfighter seems to be untouched by the destruction and loss of values left after the war that made people aimless. The owner of a hotel, Montoya, considers Jake an "aficionado": "Aficion means passion. An aficionado is one who is passionate about bull-fights" (p. 131). Jake is able to find purpose in life by learning from bullfighters. For example, he observes that "Romero's bull-fighting gave real emotion, because he kept the absolute purity of line in his movements and always quietly and calmly let the horns pass him close each time" (p. 168). He learns from Romero that even if his body is hurt his soul should remain intact: "The fight with Cohn had not touched his spirit but his face had been smashed and his body hurt. ... Each thing that he did with this bull wiped that out a little cleaner. It was a good bull, a big bull, and with horns, and it turned and recharged easily and surely. He was what Romero wanted in bulls" (p. 219). A fishing interlude with Bill Gorton in the Spanish countryside and bullfighting are, temporarily for Jake, a way out of the sexual restlessness and violence of the expatriates. When he goes fishing in the Irati River in Burguette, he is at peace: "There was no word from Robert Cohn nor from Brett and Mike" (p. 125). He and Bill lose track of time in the countryside. The English man they meet during fishing is named Harris. We know he was in the war and Bill and Jake find affinities with him. Male friendship is redeeming in keeping friends and providing them with comfort.

In the absence of conventional morality and religious sentiments, characters seek individualistic salvation, especially after the war effected a loss of faith in divine benevolence. Although Jake sometimes hates Cohn's superiority and sexual vigor, and likes the insults other characters hurl sat him as a Jew, he then feels "disgusted" at himself: "That was morality; things that made you disgusted afterward. No, that must be immorality. That was a large statement. What a lot of bilge I could think up at night" (p. 149). In Spain, Jake attends church a couple of times, once with the secular Brett. She has blurred notions of religion. She wants Jake to "go to confession" (p. 150), and Jake tells her that a confession would be "impossible" and also "in a language she did not know" (p. 151). In a San Fermin chapel in Pamplona where the fiesta started and where Brett wants to pray for Romero, they enter, and she gets nervous and leaves immediately: "I'm damned bad for a religious atmosphere," she says. "I've the wrong type of face" (p. 208). And later she says: "Never does me any good. I've never gotten anything I prayed for" (p. 209). She decides to give up Romero so that she does not destroy him: "I'm thirty-four, you know. I'm not going to be one of these bitches that ruins children" (p. 243). Mike is her "sort of thing" (p. 243). She thinks that deciding not to be a bitch is what "we have instead of God" (p. 245). These characters are not able to have stable relations in the aftermath of the war. Jake's war injury terminated the possibility for a fruitful relationship with Brett. Brett herself had lost a lover in the war through dysentery and then married and left another man traumatized 
by his war experiences to the extent of sleeping with a loaded revolver to his side. She is waiting for divorce so that she can marry the alcoholic Mike. In the meantime, she is prostituting herself with other men. Jake's impotence represents that of an entire lost generation, which in turn takes the impact of the war from the private plight of an individual to the public sphere. The broad social vision Hemingway offers is privileged over any factual or even fictional treatment of the war.

\section{Conclusion}

The Great War was a strong presence in modernist novels. The canonical novels written in the aftermath of the war were being shaped by and shaping the zeitgeist of their period. Hence, they were utilizing the public reaction to the war and recording its diverse effects and simultaneously forming the way we see modernism through them. We see in them the sensibility associated with modernism in the form of a multifaceted cultural crisis. The presence of the war in these novels indicates that they were not concerned simply with experimentation and self-conscious construction of art. Rather, they still had a valid social vision. In fact, modernism itself began as a violent movement, especially in art, in line with the violence to come during the war years. Modernist artists used aggressive rhetoric and paintings before the war, especially between 1909 and 1914. Futurism called for violently doing away with tradition and celebrating the violent dynamism, speed, and machinery of modern life. Vorticism's magazine issued by Wyndham Lewis between 1914 and 1915 was called Blast. Therefore, Milton Cohen (2001) calls the modernists" relation to war "symbiotic" and explains that "as they drew energy from these constructions of war, their own energies, in turn, were quickly sucked into the real war's immeasurably larger vortex-with profound sequences for the arts" (emphasis original; p. 160). However, the metaphorical war these artistic movements called for became an actuality. The novels written about the war in the 1920s lament the war and discuss its socio-cultural repercussions rather than document its violence as an end. Many poets, novelists, and painters took part in the war, some were killed in action, some were maimed, and some survived with nervous breakdowns or changed for life. As Cohen states, "modernism itself became a war casualty: it survived, but profoundly changed" (p. 165).

\section{References}

Aldington, R. (1929). The Death of a Hero. New York: Covici-Friede.

Bergonzi, B. (1980). Heroes' Twilight: A Study of the Literature of the Great War (2 ${ }^{\text {nd }}$ ed.). London: Macmillan. Bonadeo, A.(1989). Mark of the Beast: Death and Degradation in the Literature of the Great War. Lexington: The University Press of Kentucky.

Booth, A. (1996). Postcards from the Trenches: Negotiating the Space between Modernism and the First World War. New York: Oxford University Press.

Bradbury, M. (2001). The Modern British Novel: 1878-2001 (Rev. ed.). London: Penguin Books.

Clewell, T. (2004). Consolation Refused: Virginia Woolf, the Great War, and Modernist Mourning. Modern Fiction Studies, 50, 197-223.

Cohen, M. A. (2001). Fatal Symbiosis: Modernism and the First World War. In Patrick J. Quinn and Steven Trout (Eds.), The Literature of the Great War Reconsidered: Beyond Modern Memory (pp. 159-171). Houndmills: Palgrave.

dos Passos, J. (1927). Manhattan Transfer. London: Constable \& Co Ltd.

Fussell, P. (1975). The Great War and Modern Memory. New York: Oxford University Press. Hemingway, E. (1926). The Sun Also Rises. New York: Charles Scribner's Sons.

Hynes, S. (1991). A War Imagined: The First World War and English Culture. New York: Atheneum.

Lawrence, D. H. (1957). Lady Chatterley's Lover. New York: Grove Press.

Matsen, W. (1993). The Great War and the American Novel. New York: Peter Lang.

Matthews, S. (2004). Modernism. London: Arnold.

Muller, J. (1991). Changing Attitudes towards the War: The Impact of the First World War. British Journal of Political Science, 21(1), 1-28. Retrieved May 20, 2008, from JSTOR. Oklahoma University Library, Norman, Oklahoma.

Willis, Jr., J. H. (1999). The Censored Language of War: Richard Aldington's Death of a Hero and Three Other War Novels of 1929. Twentieth Century Literature, 45, 467-487. Retrieved April 10, 2008, from JSTOR.

Oklahoma University Library, Norman, Oklahoma.

Woolf, V. (1994). To the Lighthouse. London: Routledge. 